\title{
Constructed wetlands may lower inorganic nutrient inputs but enhance DOC loadings into a drinking water reservoir in North Wales
}

Scholz, C.; Dunn, Christian; Jones, Timothy; West, Michael; Ehbair, Abdassalam; Freeman, Christopher

\section{Environmental Science and Pollution Research}

Published: 01/09/2016

Peer reviewed version

Cyswllt i'r cyhoeddiad / Link to publication

Dyfyniad o'r fersiwn a gyhoeddwyd / Citation for published version (APA):

Scholz, C., Dunn, C., Jones, T., West, M., Ehbair, A., \& Freeman, C. (2016). Constructed wetlands may lower inorganic nutrient inputs but enhance DOC loadings into a drinking water reservoir in North Wales. Environmental Science and Pollution Research, 23(18), 18192-18199.

\section{Hawliau Cyffredinol / General rights}

Copyright and moral rights for the publications made accessible in the public portal are retained by the authors and/or other copyright owners and it is a condition of accessing publications that users recognise and abide by the legal requirements associated with these rights.

- Users may download and print one copy of any publication from the public portal for the purpose of private study or research.

- You may not further distribute the material or use it for any profit-making activity or commercial gain

- You may freely distribute the URL identifying the publication in the public portal ?

Take down policy

If you believe that this document breaches copyright please contact us providing details, and we will remove access to the work immediately and investigate your claim. 


\title{
Constructed wetlands may lower inorganic nutrient inputs but enhance DOC loadings into a drinking water reservoir in North Wales
}

\author{
C. Scholz ${ }^{a^{*}}$, T. G. Jones ${ }^{\text {b }}$, M. West ${ }^{\text {b }}$, A. M. S. Ehbair ${ }^{b}$, C. Dunn ${ }^{b}$ and C. Freeman ${ }^{b}$
}

${ }^{a}$ Department of Hydrogeology, Free University of Berlin, 12249 Berlin, Germany

${ }^{\mathrm{b}}$ School of Biological Sciences, Bangor University, Gwynedd LL57 2UW, Wales

*Author to whom all correspondence should be addressed.

e-mail: c.scholz@fu-berlin.de

\begin{abstract}
The objective of this study was to monitor a newly constructed wetland (CW) in north Wales, UK, to assess whether it contributes to an improvement in water quality (nutrient removal) of a nearby drinking water reservoir. Inflow and outflow of the Free Water Surface (FWS) CW were monitored on a weekly basis and over a period of six months. Physicochemical parameters including $\mathrm{pH}$, conductivity and dissolved oxygen (DO) were measured, as well as nutrients and dissolved organic and inorganic carbon (DOC, DIC) concentration. The CW was seen to contribute to water quality improvement; results show that nutrient removal took place within weeks after construction. It was found that $72 \%$ of initial nitrate $\left(\mathrm{NO}_{3}{ }^{-}\right), 53 \%$ of initial phosphate $\left(\mathrm{PO}_{4}{ }^{3-}\right)$ and $35 \%$ of initial biological oxygen demand (BOD) were removed, calculated as a total over the whole sampling period. From our study it can be concluded that while inorganic nutrients do decline in CWs, the DOC outputs increases. This may suggest that CWs represent a source for DOC. To assess the carbon in- and output a C budget was calculated.
\end{abstract}

Keywords: nutrient removal; carbon budget; constructed free water surface wetland

\section{Introduction}

Wetlands function as sinks for nutrients, and are often used for water quality amelioration. This nutrient retention effect is due to the accumulation of organic matter, which is based on two processes: firstly, the uptake and immobilisation of nutrients by plant, microorganisms, and soil matrix (Corbitt \& Bowen, 1994) and secondly, decomposition of organic matter, which is generally low in wetland sediments (Clymo \& Reddaway, 1971). Therefore, CWs offer a natural solution for removing nutrient pollution in aquatic ecosystems. Such low-tech treatment systems are often more economically favourable than energy-intensive engineered treatment plants, easier to operate, and provide numerous secondary benefits and are increasingly used to reduce concentrations of nitrate and phosphate in surface waters (Kadlec 2012). In England and Wales, two-thirds of drinking water comes from surface water 
(reservoirs, lakes and rivers) whilst one-third is taken from groundwater. Surface water can contain naturally high concentrations of DOC. Its removal is often the largest water treatment issue as DOC persisting until the disinfectant stage can react with the disinfectant, usually with chlorine $\left(\mathrm{Cl}^{-}\right)$to produce carcinogenic disinfection by-products (DBPs) (Chow, et al. 2003). High DOC concentrations in surface waters that feed reservoirs may be linked to catchment properties, hydrological conditions, land management characteristics, or climatic conditions (Pacheco, et al. 2013). Total organic carbon (TOC) is of multi-origin, and can be divided into two parts: autochthonous and allochthonous organic carbon. The autochthonous organic carbon is mainly controlled by the production of the algae and wetland plants; and the allochthonous one by climate and environment in the catchment area (Junlong, et al. 1997). Eutrophication, which affects many reservoirs, may present a major problem as the resulting enhanced algal growths may also increase the input of DOC, thereby increasing the potential risk of DBP formation potential (Gough, et al. 2015). Only a few studies about C budgets of CWs exist, and their results are variable but confirm that CW's often act as a net source for DOC (Kovacic, et al. 2000 and Kovacic, et al. 2006).

\section{Material and Methods}

\subsection{Site description}

The CW (figure 1) is located at one of the inflow streams of a drinking water reservoir in north Wales. The reservoir in this study is eutrophic due to agricultural practices within the catchment and the streams flowing into the reservoirs have moderate to high DOC concentrations $(\sim 10 \mathrm{mg} / \mathrm{l})$. The area around the reservoir is used for cattle and sheep farming aided by modern agro-chemicals (Hughes, et al. 2013). The bedrock at the site consists dominantly of Schist, and the aquifer has a limited yield for groundwater resources. The primary aim of the $\mathrm{CW}$ is the removal of nitrogen and phosphorus, to minimise the growth of algae in the reservoir and the formation of DBPs at the treatment plant. Phosphorus and nitrogen are high due to significant agricultural influence. The CW system consists of $414 \mathrm{~m}^{2}$ of treatment area in addition to $81 \mathrm{~m}^{2}$ of open water. The nominal hydraulic retention time (nHRT) is three days. Average inflow flow rate is $1.02 \mathrm{~L} / \mathrm{s}$. The length of the system is $33 \mathrm{~m}$, width at the inflow is 12 $\mathrm{m}$ and $18 \mathrm{~m}$ at the outflow. Furthermore $1.8 \mathrm{~m}$ were added as open water zone, which allows oxygenation, increased retention time and provides mixing, which can enhance removal processes. Mean temperature over the sampling period was $13.4^{\circ} \mathrm{C}$ and average rainfall was $3.0 \mathrm{~mm} /$ day. The treatment area comprises of a range of naturally occurring reeds, like phragmites. Only material from the site was used for construction of the walls and a series of baffles, and a plastic outflow pipe was added. In this study, we aim to investigate the time in which it takes a newly constructed wetland to improve and enhance the water quality of an inflow into a eutrophic drinking water reservoir. Therefore, physicochemical parameters at the inflow and outflow were measured on a weekly basis over a period of six months and a $\mathrm{C}$ budget was calculated.

\subsection{Field and laboratory techniques}


106

Sampling was undertaken every week between 27/03/-24/10/2014. Sampling of the CW outflow started eleven days later from the 07/04 onwards, in situ measurements were temperature and DO (Milwaukee Instruments MW-600 Smart DO Meter). At the inflow and outflow three freshwater samples were collected using a one litre glass bottle, a $100 \mathrm{ml}$ plastic bottle and a $50 \mathrm{ml}$ amber glass bottle (to minimise UV influences on samples). The one litre glass bottle was used to measure particulate organic carbon (POC) by high temperature combustion $\left(550^{\circ} \mathrm{C}\right.$ for two hours) of the sample on a GF/F Whatman glassfibre filter. The $100 \mathrm{ml}$ plastic bottle were completely filled and left unfiltered to measure $\mathrm{pH}$ (Mettler Toledo SevenEasy $\mathrm{pH}$ meter), conductivity (Orion 5 probe), bicarbonate, dissolved greenhouse gas concentrations. Bicarbonate is measured by taking $10 \mathrm{ml}$ of unfiltered sample and titrating the $\mathrm{pH}$ to 4.3 with 0.1 mole $\mathrm{HCl}$. Dissolved gases were determined using a similar headspace equilibrium method as that described by Dawson et al. (2002), with the gases analysed using a Varian 450 GC. They remaining sample was further filtered (0.45um Whatman Glass-fibre filters) and analysed for DOC and DIC concentrations (Thermalox TC/TN, Analytical Sciences Ltd), specific ultraviolet absorbance (SUVA) (Spectromax M2e Spectrophotometer, Molecular Devices) and nutrients (Metrohm 850 IC). The SUVA value gave information about the aromaticity of the water sample and is calculated with the DOC $(\mathrm{mg} / \mathrm{l})$ and the UV absorbance at $254 \mathrm{~nm}$. The $50 \mathrm{ml}$ amber bottle was incubated at room temperature for five days, so biological oxygen demand (BOD) could be calculated. With the Thermalox, DOC, DIC and total carbon (TC) concentrations were measured to calculate the $\mathrm{C}$ budget (slighlty altered from Pacheco et al. 2013) of the wetland. To assess carbon processing, the following mass balance equation was applied:

where TOC is total organic carbon, OC is organic carbon, the subscripted "in" signifies the inflow from the catchment, "dep" is atmospheric wet deposition, "out" is outflow from the lake, "s" is permanent burial in sediment, $\mathrm{CO}_{2}$ is the concentration of $\mathrm{CO}_{2}$ in the water. Additionally $\mathrm{CH}_{4}$ was calculated as a $\mathrm{CO}_{2}$ equivalent and added to the $\mathrm{CO}_{2} . \Delta \mathrm{TC}$ st is the change in the pool of $\mathrm{C}$ in the lake over each sampling time period (one week). $\mathrm{POC}_{\mathrm{in}}, \mathrm{DOC}_{\mathrm{in}}, \mathrm{DIC}_{\mathrm{in}}, \mathrm{POC}_{\text {out }}$, $\mathrm{DOC}_{\text {out }}, \mathrm{DIC}_{\text {out }}$ were calculated from weekly measured concentrations in streams.

To assess the effectiveness of the wetland nutrient removal efficiency (R) was calculated as follow 
Nutrient concentration influent $(\mathrm{Ci})$ was measured at the inflow and the nutrient concentration effluent (Co) was sampled at the outflow both on a weekly basis and for calculation of $\mathrm{R}$ the average mean value was used.

\section{Results}

114 Mean DOC concentration of the inflow was $7.22 \pm 0.17 \mathrm{mg} / \mathrm{l}$ and average DIC concentration was 18.07 $115 \pm 0.21 \mathrm{mg} / \mathrm{l}$. As seen in figure 2 , the DOC concentration of the outflow was in general higher than the 116 inflow, but both exhibiting the same approximate seasonal trend. The carbon budget (figure 3) shows 117 that over the entire sampling period $17.2 \%$ less DIC, $11.5 \%$ more DOC and approximately twice as 118 much POC flowed into the reservoir compared to if the CW didn't exist. 7.5\% of the carbon is retained

119 in the wetland through sedimentation and plant uptake. Nutrient removal efficiency is $-60.7 \%$. Mass 120 removal rate (MRR) was $-0.92 \mathrm{~g} \cdot \mathrm{m}^{-2} \mathrm{~d}^{-1}$ calculated as mean average over the whole sampling period. 121 Pearson correlation factors for DIC, removal DIC, DOC, removal DOC, removal POC, SUVA and removal SUVA were calculated with SPSS (table 1).

\section{$3.2 U V_{254}$ and SUVA}

Mean outflow $\mathrm{UV}_{254}$ was $0.34 \pm 0.005 \mathrm{~nm}$ and for the inflow $0.20 \pm 0.004 \mathrm{~nm}$. $\mathrm{UV}_{254}$ concentration increased and was higher than inflow concentrations, till the beginning of July, afterwards it decreased and concentrations fell below inflow values. Mean SUVA value at the inflow was $3.49 \pm 0.06$ and for the outflow $3.13 \pm 0.04$. After initially high (>4) SUVA values at the outflow during start-up phase, SUVA concentration stabilises to values lower than four at the end of April, with only a short rise at the end of August. Outflow waters have a higher DOC concentration and higher UV254 absorbance. The SUVA removal rate over the whole sampling period was $10.2 \%$.

\subsection{Nutrients}

134 Nitrate concentration (figure 4) was $4.5 \pm 0.15 \mathrm{mg} / \mathrm{l}$ (inflow) and $1.2 \pm 0.09 \mathrm{mg} / \mathrm{l}$ (outflow). Nitrate removal was effectively working two months after construction but concentration increased at the end of the sampling period. Nitrate removal rates over the whole sampling period were $72 \%$. Removal of DIC and $\mathrm{O}_{2}$ were negatively correlated with $\mathrm{NO}_{3}$ removal rates (table 2). Nitrate removal rates decline drastically in autumn, with an acculumulation rate $>80 \%$. Nitrate removal was positively correlated with $\mathrm{PO}_{4}{ }^{3-}$ removal rates (table 2). MMR of nitrate was $0.70 \mathrm{~g} \cdot \mathrm{m}^{-2} \mathrm{~d}^{-1}$.

140 Phosphate removal rate was 53.4\% as an average over the sampling period. Phosphate concentration of 141 the outflow is in general higher than at the inflow, seeming to follow a time delayed peak pattern. 142 Phosphate MMR was $0.0043 \mathrm{~g} \cdot \mathrm{m}^{-2} \mathrm{~d}^{-1}$. Mean average phosphate (figure 5) concentration was 0.04 $143 \pm 0.0018 \mathrm{mg} / \mathrm{l}$ (inflow) and $0.02 \pm 0.0021 \mathrm{mg} / \mathrm{l}$ (outflow). 
144 Bromide concentration (figure 6) at the inflow was $\sim 0.07 \mathrm{mg} / \mathrm{l}$ and $\sim 0.1 \mathrm{mg} / \mathrm{l}$ at the outflow. Bromide 145 concentration at inflow and outflow are quite similar for the first three and a half months, afterwards 146 bromide concentration at the outflow rises to about one third of the concentration at the inflow. MMR 147 was calculated as $-0.0049 \mathrm{~g} \cdot \mathrm{m}^{-2} \mathrm{~d}^{-1}$. Nutrient removal efficiency was $-31.5 \%$.

\subsection{Dissolved oxygen, temperature and $\mathrm{pH}$}

150 Dissolved oxygen increased by $4.5 \%$ from inflow to outflow, the average $\mathrm{BOD}_{5}$ was reduced to $46 \%$. 151 The average DO value at the outflow was $7.89 \pm 0.22 \mathrm{mg} / \mathrm{l}$. The outflow of the wetland was by average 1526.6 degrees warmer than the inflow. Outflow temperature was $19.5 \pm 0.2{ }^{\circ} \mathrm{C}$ on average. Mean inflow $153 \mathrm{pH}$ was $7.7 \pm 0.2$ and at the outflow it was $7.6 \pm 0.3$. Pearson correlation factors for DO, BOD, $\mathrm{pH}$, removal $\mathrm{pH}$, temperature and conducitivity were calculated with SPSS (table 3).

\subsection{Greenhouse Gases}

The concentration of greenhouse gases (GHGs), especially $\mathrm{CH}_{4}$ rose significantly and was by average over the sampling period almost ten times higher at the outflow compared to the inflow. Average $\mathrm{CH}_{4}$ emission at the outflow was $20.11 \pm 0.56 \mu \mathrm{g} / \mathrm{l}$ and $2.11 \pm 0.16 \mu \mathrm{g} / \mathrm{l}$ at the inflow. By the end of June, $\mathrm{CH}_{4}$ concentration decreased and rose again in August (figure 7). From the last September week onwards the concentration of $\mathrm{CH}_{4}$ at the outflow stopped exceeding the one at the inflow. Table 4 shows a positive correlation between $\mathrm{CH}_{4}$ and $\mathrm{UV}_{254}$ removal rate. The $\mathrm{CO}_{2}$ concentration was approximately twice as high at the outflow $\sim 1130 \pm 25.15 \mathrm{mg} / \mathrm{l}$ compared to the inflow. The outflow concentration increased steadily until the end of September; afterwards it declined and dropped under the concentration of the inflow (figure 8).

\section{Discussion}

This study aimed to investigate the nutrient removal capabiltiy of a new CW and the effect it has on carbon cycling. Since only one site was monitored no general assumptions can be made but the results show an unexpected trend of DOC concentration increase, which should be further investigated. According to Pinney et al. (2000) and Villa et al. (2014) CW plants function as a net source of DOC. While inorganic nutrients were sequestered in this $\mathrm{CW}$, achieving the main aim of their installation, the DOC outputs increased. DOC can be leached into water flowing through wetlands as plants, algae, and bacteria grow, die and decay (Pinney, et al. 2000). According to Lin et al. (2002) macrophytes present species-specific nitrate removal efficiency, depending on their ability to produce carbon for denitrificiation. DOC and bromide accumulation increases the likelihood of DB production in the form of trihalomthanes (THMs) and halacetonitiles (HANs). Some of these DBPs are suspected to be mutagens, carcinogens or developmental toxicants if ingested over extended periods of time 
brominated DBPs, which are generally more toxic than chlorinated DBPs (Richardson, et al. 2007). According to Ingersoll \& Baker (1998) when nitrate removal efficiencies increase, dissolved organic carbon in the effluent also increases, as does chloroform formation potential. Bacterial decomposition of plant detritus has been shown to convert POC into dissolved form and cause the release of humic substances into the bulk DOC pool (Moran \& Hodson 1994). Particulate organic carbon causes the formation of anaerobic microsites, supporting simultaneous nitrification and denitrification. Therefore it may play a dual role in denitrification, since it supports the heterotrophic metabolism of denitrifying bacteria as well as the $\mathrm{O}_{2}$ consumption which creates anaerobic microsites necessary for denitrification (Hamersley \& Howes 2002). The accumulation of twice as much POC in the constructed wetland enhances denitrification processes. Bioavailable POC acts not only as a $\mathrm{C}$ substrate for denitrifiers, but also depletes DO levels within particles via aerobic respiration, supporting denitrification within aerobic wastewaters. According to Moran \& Hodson (1994) higher POC additions results in higher respiration rates, and the faster creation of anaerobic microsite volume to support denitrification. SUVA is a reliable indicator of the aromaticity and liability of natural organic matter (NOM) to coagulation and it is known that the NOM in high-SUVA waters tends to have lower alkalinities and hardness and higher TOC concentrations and is therefore more amenable to removal by coagulation at the treatment works (Archer \& Singer 2006). Results show that despite the rise in DOC concentration at the outflow, SUVA values decrease. This means that the added DOC will be easier to treat and has most likely less potential to form THMs. Initial phosphate concentration at the inflow most likely originates from $\mathrm{PO}_{4}{ }^{3-}$ in the soil, which was released during construction work. Later increasing phopshate concentration were proberly due to agricultural nutrients leaching into the surface water, which is benefical for plants growths. According to Verhoeven \& Meuleman (1999) in most CWs, phosphate removal does not exceed more than 50\%. Dissolved oxygen increased due to the growing vegetation in the start-up phase. A survey conducted by Puigagut et al. (2007) stated that $\mathrm{BOD}_{5}$ removal generally ranged from $80-95 \%$. For denitrification, DOC is a key factor as well as DO, as an anaerobic environment is needed. As in previous research conducted, denitrification rates are mainly constrained by environemntal conditions such as temperature, pH and carbon availabiliy (Song, et al. 2011 and Bachand \& Horne, 2000).

The concentration pattern of GHGs can be explained by vegetation growth phases over the sampling period. Plants are the main source of carbon for microorganisms in CWs. This carbon is further transformed to gaseous forms and increases the loading of $\mathrm{CO}_{2}$ and $\mathrm{CH}_{4}$ into the wetland. Furthermore plants increase the efficiency of nitrogen removal by supporting denitrifying microorganisms with easily decomposable organic matter (Picek, et al. 2007). In a study conducted by Liikanen et al. (2006) it was estimated that even if all global wastewaters were treated in constructed wetlands, their share in atmospheric liability would be less than $1 \%$ in total. 


\section{Conclusion}

Because newly CWs have not been previously monitored during start-up phase, weekly monitoring over a six months period was meant to give insight into the early stage functionality. From this study it can be seen that newly constructed wetlands contribute to water quality improvement within a few weeks after construction. Nitrate and $\mathrm{BOD}_{5}$ removal started showing an effect from the end of April onwards, within four weeks after construction. Nitrate removal was the fastest and most efficient process, probably boosted by the very rapidly establishing vegetation around the $\mathrm{CW}$. The plants leached organic matter into the wetland, which increased DOC concentration, nevertheless the DOC built up, is less likely to form THMs. By the beginning of September nitrate was accumulated in the CW, possibly due to the fact that vegetation started to decrease and could not take up nitrate as over the spring/summer months. Evergreen plants for vegetation might be a valid solution to produce less organic matter and take up nitrate all year around.

\section{Acknowledgement}

Thanks to the Wolfson Carbon Capture Laboratory Team for their support, Natural Resources Wales and the MET office for providing data.

\section{References}

Archer, A. D., \& Singer, P. C. (2006). An evaluation of the relationship between SUVA and NOMcoagulation using ICR database. J. Am. Water Works Assoc. 98 (7), 110-123.

Bachand, P. A., \& Horne, A. J. (2000). Denitrification in constructed free-water surface wetlands: II.Effects of vegetation and temperature. Ecological Engineering.

Chow, A. T., Tanji, K. K., \& Gao, S. (2003). Production of dissolved organic carbon (DOC) and trihalomethane (THM) precursor from peat soils. Water Research Vol. 37 , 4475-4485.

Clymo, R. S., \& Reddaway, E. J. (1971). Producitivity of Sphagnum (bog-moss) and peat accumulation. Hydriobiologia Vol. 12, 181-192.

Corbitt, R. A., \& Bowen, P. (1994). Constructed wetlands for wastewaster treatment. In D. M. Kent, Applied Wetlands Science and Technology (p. Chapter 10). Florida: CRC Press.

Dawson, J. J., Billett, M. F., Neal , C., \& Hill, S. (2002). A comparison of particulate, dissolved and gaseous carbon in two contrasting upland streams in the UK. Journal of Hydrology, 226-246.

Gough, R., Holliman, P. J., Cooke, G. M., \& Freeman, C. (2015). Characterisation of algogenic organic matter during an algal bloom and its implications for trihalomethane formation. Sustainability of Water Quality and Ecology.

Hamersley, M. R., \& Howes, B. L. (2002). Control of denitrification in a septage-treating artificial wetland: the dual role of particulate organic carbon. Water Research Vol. 39, 4415-4427. 
Hughes, D. D., Holliman, P. J., Jones, T., \& Freeman, C. (2013). Temporal variations in dissolved organic carbon concentrations in upland and lowland lakes in North Wales. Water and Environmental Journal, 275-283.

Ingersoll, T. L., \& Baker, L. A. (1998). Nitrate Removal in Wetland microcosms. Water Research Vol. 32 No. 3, 667-684.

Junlong, Q., Sumin, W., Bin, X., Rusong, C., \& Shanzhe, K. (1997). A method of quantitatively calculating amount of allochthonous organic carbon in lake sediments . Chinese Science Bulletin VOl. 42 No.21, 1821-1823.

Kadlec, R. H. (5. May 2012). Constructed Marshes for Nitrate Removal. Critical Reviews in Environmental Science and Technology.

Kovacic, D. A., David, M. B., Gentry, L. E., Starks, K. M., \& Cooke, R. A. (2000). Effectiveness of Constructed Wetlands in Reducing Nitrogen and Phosphorus Export from Agricultural Tile Drainage. Joumal of Environmental Quality Vol. 29 No.4, 1262-1274.

Kovacic, D. A., Twait, R. M., Wallace, M. P., \& Bowling, J. M. (2006). Use of created wetlands to improve water quality in the Midwest—Lake Bloomington case study. Ecological Engineering Vol.28, 258-270.

Liikanen, A., Huttunen, J. T., Karjalainen, S. M., Väisänen, T. S., Nykänen, H., \& Martikainen, P. J. (2006). Spatial and seasonal variation in greenhouse gas emissions from a constructed wetland purifying peat mining runoff waters. Ecological Engeneering Vol.26, 241-251.

Lin, Y.-F., Jing, S.-R., Wang, T.-W., \& Lee, D.-Y. (2002). Effects of macrophytes and external carbon sources on nitrate removal from groundwater in constructed wetlands. Environmental Pollution Vol.119, 413-420.

Moran, M. A., \& Hodson, R. E. (1994). Dissolved humic substances of vascular plant origin in a coastal marine environment. Limnol. Oceanogr. Vol. 39 (4), 762-771.

Pacheco, F. S., Roland, F., \& Downing, J. A. (2013). Eutrophication reverses whole-lake carbon budgets. Inland Waters, 41-48.

Picek, T., Cízková, H., \& Dusek, J. (2007). Greenhouse gas emissions from a constructed wetlandPlants as important sources of carbon. Ecological Engineering Vol. 31, 98-106.

Pinney, M. L., Westerhoff, P. K., \& Baker, L. (2000). Transformations in dissovled organic carbon through constructed wetlands. Water Research Vol. 34, 1897-1911.

Puigagut, J., Villasenor, J., Salas, J. J., Bécares, E., \& García, J. (2007). Subsurface-flow constructed wetlands in Spain for the sanitatom of small communities: A comparative study. Ecological Engeneering Vol.30, 312-319.

Richardson, S. D., Plewa, M. J., Wagner, E. D., Schoeny, R., \& DeMarini, D. M. (2007). Occurrence, genotoxicity, and carcinogenicity of regulated and emerging disinfection by-products in drinking water: A review and roadmap for research. Mutation Research 636, 178-242. 
Song, K., Lee, S.-H., \& Kang, H. (2011). Denitrification rates and community structure of denitrifying bacteria in newly constructed wetland. European Journal of Soil Biology Vol.47, 24-29.

290 Verhoeven, J. T., \& Meuleman, A. F. (1999). Wetlands for wastewater treatment: Opportunities and limitations. Ecological Engineering Vol. 12, 5-12.

292 Villa, J. A., Mitsch, W. J., Song, K., \& Miao, S. (2014). Contribution of different wetland plant species to the DOC exported from a mesocosm experiment in the Florida Everglades. Ecological Engineering 71, 118-125.

295 Villanueva, C. M., Cantor, K. P., Cordier, S., Jaakkola, J. J., King, W. D., Lynch, C. F., et al. (2004). Disinfection Byproducts and Bladder Cancer- A Pooled Analysis. Epidemiology Vol. 15 No. 3 , 357-366. 